Article

\title{
Avoidable Blood Loss in Critical Care and Patient Blood Management: Scoping Review of Diagnostic Blood Loss
}

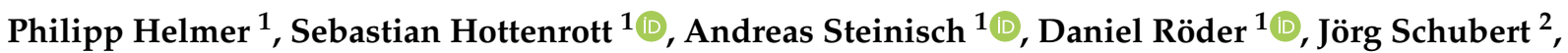 \\ Udo Steigerwald $^{2}$, Suma Choorapoikayil ${ }^{3}$ and Patrick Meybohm ${ }^{1, *(1)}$
}

1 Department of Anaesthesiology, Intensive Care, Emergency and Pain Medicine, University Hospital Würzburg, Oberdürrbacher Str. 6, 97080 Wuerzburg, Germany; helmer_p@ukw.de (P.H.); hottenrott_s@ukw.de (S.H.); Steinisch_a@ukw.de (A.S.); roeder_d@ukw.de (D.R.)

2 Department of Laboratory Medicine and Coagulation Ambulance, University Hospital Würzburg, Oberdürrbacher Str. 6, 97080 Würzburg, Germany; schubert_j@ukw.de (J.S.); steigerwald_u@ukw.de (U.S.)

3 Department of Anaesthesiology, Intensive Care Medicine and Pain Therapy, University Hospital Frankfurt, Goethe-University, 60323 Frankfurt, Germany; Suma.Choorapoikayil@kgu.de

* Correspondence: meybohm_p@ukw.de

check for updates

Citation: Helmer, P.; Hottenrott, S.; Steinisch, A.; Röder, D.; Schubert, J. Steigerwald, U.; Choorapoikayil, S.; Meybohm, P. Avoidable Blood Loss in Critical Care and Patient Blood Management: Scoping Review of Diagnostic Blood Loss. J. Clin. Med. 2022, 11, 320. https://doi.org/ $10.3390 /$ jcm 11020320

Academic Editor: William Hurford

Received: 6 December 2021

Accepted: 4 January 2022

Published: 10 January 2022

Publisher's Note: MDPI stays neutral with regard to jurisdictional claims in published maps and institutional affiliations.

Copyright: (C) 2022 by the authors. Licensee MDPI, Basel, Switzerland. This article is an open access article distributed under the terms and conditions of the Creative Commons Attribution (CC BY) license (https:// creativecommons.org/licenses/by/ $4.0 /)$.

\begin{abstract}
Background: Anemia remains one of the most common comorbidities in intensive care patients worldwide. The cause of anemia is often multifactorial and triggered by underlying disease, comorbidities, and iatrogenic factors, such as diagnostic phlebotomies. As anemia is associated with a worse outcome, especially in intensive care patients, unnecessary iatrogenic blood loss must be avoided. Therefore, this scoping review addresses the amount of blood loss during routine phlebotomies in adult (>17 years) intensive care patients and whether there are factors that need to be improved in terms of patient blood management (PBM). Methods: A systematic search of the Medline Database via PubMed was conducted according to PRISMA guidelines. The reported daily blood volume for diagnostics and other relevant information from eligible studies were charted. Results: A total of 2167 studies were identified in our search, of which 38 studies met the inclusion criteria (9 interventional studies and 29 observational studies). The majority of the studies were conducted in the US (37\%) and Canada (13\%). An increasing interest to reduce iatrogenic blood loss has been observed since 2015. Phlebotomized blood volume per patient per day was up to $377 \mathrm{~mL}$. All interventional trials showed that the use of pediatric-sized blood collection tubes can significantly reduce the daily amount of blood drawn. Conclusion: Iatrogenic blood loss for diagnostic purposes contributes significantly to the development and exacerbation of hospital-acquired anemia. Therefore, a comprehensive PBM in intensive care is urgently needed to reduce avoidable blood loss, including blood-sparing techniques, regular advanced training, and small-volume blood collection tubes.
\end{abstract}

Keywords: PBM; critically ill; intensive care; iatrogenic anemia; avoidable blood loss; diagnostic blood loss

\section{Introduction}

\subsection{Anemia in Critically Ill Patients}

Anemia is a common comorbidity in intensive care patients with a prevalence of up to $98 \%$ [1], of which $40-50 \%$ suffer from severe anemia (hemoglobin $<9 \mathrm{~g} / \mathrm{dL}$ ) [2] Several studies have repeatedly demonstrated that anemia increases the administration of allogeneic blood products and is furthermore associated with an increased complication rate, prolonged hospital stay, and increased mortality rate [3,4]. Particularly, in patients with COVID-19 infection, mortality rate increases significantly in the presence of anemia, from $8 \%$ to $25 \%$, compared to COVID-19 patients without anemia [5]. McEvoy et al. revealed that anemia increases the 90 day mortality rate in patients with chronic obstructive pulmonary disease (COPD) from $25 \%$ to $57 \%$ [6,7]. The authors also revealed that, in patients with congestive heart failure, acute myocardial infarction, or chronic kidney 
disease, an increased rate of adverse events was observed in anemic patients compared to non-anemic patients [6]. It is noteworthy to mention that critically ill anemic patients often show a prolonged hospital stay after discharge from ICU [8]. Cioc et al. evaluated the impact of daily phlebotomy in intensive care patients on hemoglobin levels and found that both the absolute hemoglobin value and dynamics of the hemoglobin drop play an important role. The difference between hemoglobin values at admission to an ICU and at discharge is associated with an increased overall mortality [9]. The mainstay of anemia treatment in critically ill patients is transfusion of allogenic red blood cell (RBC) units. Up to $85 \%$ of the patients with an ICU stay $>7$ days received at least one unit of RBC [10].

\subsection{Pathophysiology of Anemia in Critically Ill Patients}

The causes of anemia are multifactorial, including pathophysiological and iatrogenic factors. Healthy adults produce $0.25 \mathrm{~mL} / \mathrm{kg}$ RBCs per day, resulting in $0.5 \mathrm{~L}$ blood per week, whereas in critically ill patients, erythropoiesis is often impaired, leading to a reduced amount of newly produced RBCs [6]. Table 1 summarizes iatrogenic and pathophysiological factors that are associated with the development of anemia in critically ill patients $[2,11,12]$.

Table 1. Causes for anemia in critically ill patients.

\begin{tabular}{cc}
\hline \multicolumn{1}{c}{ Pathophysiological Causes for Anemia } & Iatrogenic Causes for Anemia \\
\hline $\begin{array}{c}\text { Inflammation leads to: } \\
\text { - }\end{array} \begin{array}{c}\text { Impairment of erythropoiesis } \\
\text { Reduction of RBC maturation and life span }\end{array}$ & Frequency and volume of phlebotomies \\
\hline $\begin{array}{c}\text { Endogenous kidney dysfunction with low EPO } \\
\text { concentration }\end{array}$ & $\begin{array}{c}\text { Hemolysis due to ECMO-therapy and } \\
\text { CRRT }\end{array}$ \\
\hline Altered iron metabolism & Blood volume discarded \\
\hline $\begin{array}{c}\text { Nutritional deficiency of iron, folate, vitamin B12 } \\
\text { Fluid shift due to sepsis }\end{array}$ & $\begin{array}{c}\text { Coagulation disorders due to } \\
\text { pharmacotherapy }\end{array}$ \\
\hline Major hemorrhages & Impaired /insufficient enteral feeding \\
\hline Occult bleedings & Fluid resuscitation in septic patients \\
\hline $\begin{array}{c}\text { Coagulation disorders due to thrombocytopenia } \\
\text { and liver synthesis disorders }\end{array}$ & Surgical interventions \\
\hline $\begin{array}{c}\text { EPO = Erythropoietin. CRRT = continuous renal replacement therapy. ECMO = extracorporeal membrane } \\
\text { oxygenation. }\end{array}$ &
\end{tabular}

Erythropoiesis is impaired in critically ill patients and results in reduced RBC production $[13,14]$ due to the reduced life span of RBCs, elevated expression of inflammatory cytokines (TNF-alpha and Interleukin 1) [2,15,16], endogenous kidney dysfunction (leading to decreased serum erythropoietin (EPO) concentrations) [1], and reduced response from reticulocytes to EPO [1]. The administration of erythropoiesis-stimulating agents (ESA) can compensate for absolute or relative EPO deficiency, improving $\mathrm{Hb}$ levels in intensive care patients $[13,17]$. Almost $40 \%$ of ICU patients show changes in iron metabolism, $9 \%$ nutritional iron deficiency, and 2\% low folate or Vitamin B12 [6,18-20]. In addition, hemolysis, particularly in patients with ARDS, sepsis, and post-administration of RBC units [21], fluid resuscitation (leading to dilutional anemia) [2,22], major hemorrhages (in 8.4\%), and occult hemorrhages (in 90\%) [1,6,23-25] can aggravate anemia by coagulation disorders [26] or by drug-induced changes in blood coagulation, e.g., by administration of anticoagulants.

Iatrogenic factors include all types of medical interventions associated with potential blood loss or factors contributing to impaired erythropoiesis. The impact of iatrogenic anemia was highlighted in the early 1970s as nosocomial anemia but is still a persisting problem [27-29]. Corwin et al. demonstrated an association between the daily volume of diagnostic blood draws, length of stay, and the number of allogenic RBC units [10]. In case the total volume for diagnostic blood draws increased to $2156 \pm 208 \mathrm{~mL}$, patients required 
more than 10 units of RBCs compared to $601 \pm 77 \mathrm{~mL}$ blood loss with no transfused RBC units. In cardiac surgical patients, diagnostic blood sampling resulted in $653 \mathrm{~mL}$ blood loss, which corresponds to 1-2 RBC units [28]. In individual cases of very long hospital stays of more than 100 days, the volume of blood collected even exceeded 12 L [28]. Interestingly, even small increases of daily phlebotomies doubled the likelihood of allogenic blood transfusions after day 21 [30].

In addition to the blood used for diagnostic purposes, high volumes of blood are often discarded during blood withdrawal if blood-saving collection systems are not used. Importantly, clinical trials in patients requiring intensive care can also contribute to iatrogenic anemia. Depending on the study design, PETAL network recommended a maximal research blood volume of $120 \mathrm{~mL} / \mathrm{d}$ [31]. The estimated blood loss is much higher in ICU patients than in a surgical ward (up to $10 \mathrm{~mL} /$ day) or in renal inpatients [32,33]. Particularly on the day of ICU admission, the volume of daily blood collected for diagnostic purposes is the highest and decreases during the ICU stay $[1,33]$.

\subsection{Patient Blood Management}

Based on the possibilities to strengthen and preserve patients' own blood mass and to enable safe handling of donor blood, the World Health Assembly (WHA 63.12) [34] endorsed patient blood management (PBM) and called on the World Health Organization in 2010 to provide training to its member states on the safe and rational use of allogeneic blood products and implementation of transfusion alternatives.

PBM is an interdisciplinary concept based on three pillars, with the aim to increase patient safety using diagnostic, therapeutic, and behavioral concepts. More than 100 specific measures [35] were designed to (1) provide comprehensive anemia management, (2) minimize iatrogenic (unnecessary) blood loss, and (3) harness and optimize the patient-specific physiological tolerance of anemia [36]. To reduce iatrogenic blood loss, PBM includes the use of autologous blood recovery systems, restrictive frequency of blood draws, use of reduced blood volume collection tubes and blood-sparing techniques, and accurate documentation of all blood losses. This scoping review focuses on iatrogenic anemia caused by phlebotomy and possible measures to reduce blood loss during diagnostics in critical care patients.

\section{Materials and Methods}

\subsection{Study Design}

This scoping review was reported according to the recommendations of PRISMA using Medline for systematic search [37]. No study protocol was published. Eligibility criteria were defined prior to literature search. All randomized or nonrandomized controlled trials, observational, prospective, or retrospective studies reporting daily volume of blood taken for laboratory diagnostics in an adult ICU were included. Expert opinions and individual case reports were excluded. Furthermore, reference lists of scooping reviews, systematic reviews, and meta analyses were screened. Trials including patients who were $<18$ years, non-human species, non English or German language, or for whom no full text was available even after contacting the authors were excluded from analysis. There were no specifications for length of stay on an ICU.

\subsection{Information Sources}

The literature search was conducted in August 2021. The search term was compiled jointly by the authors after extensive discussions before the systematic literature search started. The search was deliberately based exclusively on keywords in the title and abstract in order to specify the search. Titles with unclear relevance were discussed in detail by the reviewers. All relevant information of the identified studies was discussed and independently summarized by two reviewers. 


\subsection{Search Term}

The search term contained relevant terms on diagnostic blood loss, blood draws, and iatrogenic anemia in intensive care patients. This can be found in Appendix A.

\subsection{Data Items}

The primary endpoint was the volume of daily blood draws and, if indicated, the cumulative volume of blood draws. Secondary endpoints were measures to avoid or reduce blood loss and the use of RBC units. For both the identified observational and intervention studies, in addition to the first author, the year of publication, the country, or region in which the study was conducted, the patient population under observation, including size of the cohort studied, the study design, and the length of time patients received intensive care therapy, was reported.

\section{Results}

Based on the systematic search, 2149 titles were found in Medline with exclusive consideration of adult cohorts ( $>18$ years) and a further 18 studies were found by a hand search, resulting in 2167 possible eligible studies. After screening title and abstracts, 2034 studies were excluded, and 133 studies were considered for full text search. A total of 94 studies were further excluded: 46 studies provided no explicit data on daily blood draws, 37 studies focused on other topics, 9 studies could not be translated for the purposes of this study, for 2 studies, no full text was available even after contacting the authors, and 1 study included non-human species. The remaining 38 studies were grouped according to the study design (observational and interventional) and analyzed separately (Figure 1). Details about included studies are shown in Tables 2 and 3.

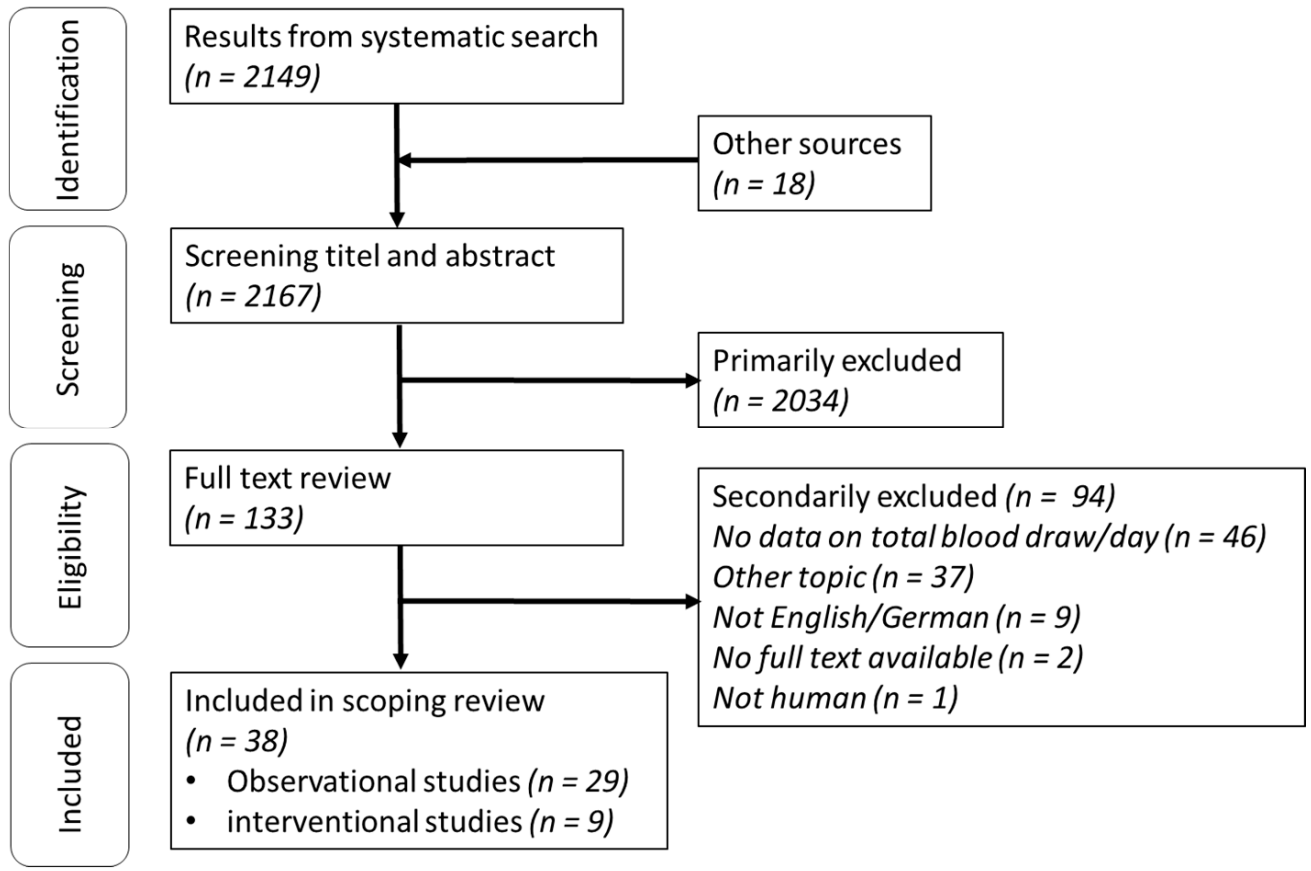

Figure 1. Flow chart of systematic search. $n=$ number. 
Table 2. Interventional studies.

\begin{tabular}{|c|c|c|c|c|c|c|c|c|c|c|}
\hline Author & Year & $\begin{array}{l}\text { Country/ } \\
\text { Region }\end{array}$ & $\begin{array}{l}\text { Study } \\
\text { Design }\end{array}$ & $\begin{array}{c}\text { Number } \\
\text { Population } \\
(n)\end{array}$ & $\begin{array}{l}\text { Cohort } \\
\text { (ICU) }\end{array}$ & Intervention & $\begin{array}{l}\text { Mean Phle- } \\
\text { botomy } \\
\text { Volume } \\
\text { (mL/d) }\end{array}$ & $\begin{array}{l}\text { Length of } \\
\text { Stay on } \\
\text { ICU for } \\
\text { Inclusion }\end{array}$ & $\begin{array}{l}\text { Effects on } \\
\text { Blood } \\
\text { Transfusion } \\
\text { (Transfused } \\
\text { Patients \%) }\end{array}$ & $\begin{array}{l}\text { Days on } \\
\text { ICU }\end{array}$ \\
\hline $\begin{array}{c}\text { Briggs et al. } \\
\text { [38] }\end{array}$ & 2019 & AUS & $\begin{array}{l}\text { C, before- } \\
\text { and-after } \\
\text { study }\end{array}$ & 318 & General & $\begin{array}{c}\text { Pediatric } \\
\text { tubes vs. } \\
\text { control tubes }\end{array}$ & $\begin{array}{c}15-16 \text { vs. } \\
28-32\end{array}$ & $48 \mathrm{~h}$ & n.s. ${ }^{1,2}$ & / \\
\hline $\begin{array}{c}\text { Garcia et al. } \\
\text { [39] }\end{array}$ & 2020 & USA & $\mathrm{Ra}, \mathrm{C}$ & 200 & Medical & $\begin{array}{c}\text { Pediatric } \\
\text { tubes vs. } \\
\text { control tubes }\end{array}$ & $\begin{array}{l}8.6(4-18) \\
\text { vs. } 21.6 \\
(15-31)\end{array}$ & $<12 \mathrm{~h}$ & $6 \%$ vs. $11 \%$, n.s & $\begin{array}{l}2.5(1.5-4) \\
\text { vs. } 2.5 \\
(1.5-5)\end{array}$ \\
\hline $\begin{array}{l}\text { Macisaac } \\
\text { et al. [40] }\end{array}$ & 2003 & AUS & $\begin{array}{c}\text { Ra, C, } \\
\text { unblinded }\end{array}$ & 160 & General & $\begin{array}{c}\text { Blood } \\
\text { conservation } \\
\text { devices vs. } \\
\text { control }\end{array}$ & $\begin{array}{c}63(0-787) \\
\text { vs. } 133 \\
(7-1227)^{4}\end{array}$ & $\begin{array}{c}\text { After } \\
\text { admission }\end{array}$ & $\begin{array}{c}30 \% \text { vs. } 17 \% \\
\quad(p=0.04)\end{array}$ & $\begin{array}{c}3.1(0.2-30) \\
\text { vs. } 2.0 \\
(0.2-54)\end{array}$ \\
\hline $\begin{array}{l}\text { Peruzzi } \\
\text { et al. [41] }\end{array}$ & 1993 & USA & Pro, $\mathrm{Ra}, \mathrm{C}$ & 100 & Medical & $\begin{array}{c}\text { Blood } \\
\text { conservation } \\
\text { devices vs. } \\
\text { control }\end{array}$ & $\begin{array}{l}19.4 \pm 47.4 \\
\text { vs. } 103.5 \pm \\
99.9\end{array}$ & / & $\begin{array}{c}26 \% \text { vs. } 32 \% \text {, } \\
\text { n.s }\end{array}$ & $\begin{array}{c}4.1 \pm 3.6 \mathrm{vs} \\
4.6 \pm 4.9\end{array}$ \\
\hline $\begin{array}{l}\text { Pinto et al. } \\
\text { [42] }\end{array}$ & 2018 & CAN & $\begin{array}{l}\text { Pro, before- } \\
\text { after } \\
\text { design }\end{array}$ & 369 & Cardio & $\begin{array}{c}\text { Pediatric } \\
\text { tubes vs. } \\
\text { control tubes }\end{array}$ & $\begin{array}{l}6 \text { (4-8) vs. } \\
11(8-17)\end{array}$ & / & $\begin{array}{l}20 \% \text { vs. } 28 \% \text { ( } p \\
\quad=0.08)\end{array}$ & $1(1-35)$ \\
\hline $\begin{array}{l}\text { Silver et al. } \\
\text { [43] }\end{array}$ & 1993 & USA & $\begin{array}{l}\text { Pro, Ra, } \\
\text { crossover } \\
\text { compari- } \\
\text { son }\end{array}$ & 31 & Medical & $\begin{array}{c}\text { Blood } \\
\text { conservation } \\
\text { devices vs. } \\
\text { control }\end{array}$ & $36.77^{5}$ & $<48 \mathrm{~h}$ & / & / \\
\hline $\begin{array}{l}\text { Dolman } \\
\text { et al. [22] }\end{array}$ & 2015 & USA & $\begin{array}{l}\text { Re, before- } \\
\text { and-after } \\
\text { study }\end{array}$ & 248 & $\begin{array}{l}\text { Medical } \\
\text { and } \\
\text { surgical }\end{array}$ & $\begin{array}{c}\text { Pediatric } \\
\text { tubes vs. } \\
\text { control tubes }\end{array}$ & $\begin{array}{l}22.5 \pm 17.3 \\
\text { vs. } 31.7 \pm \\
15.5\end{array}$ & $48 \mathrm{~h}$ & $\begin{array}{c}4.4 \pm 3.6 \text { vs. } 6.0 \\
\pm 8.2 \text { RBC units, } \\
\text { n.s. }\end{array}$ & / \\
\hline $\begin{array}{l}\text { Riessen } \\
\text { et al. [44] }\end{array}$ & 2015 & DEU & $\begin{array}{l}\text { Re, before- } \\
\text { and-after } \\
\text { study }\end{array}$ & 91 & Medical & $\begin{array}{l}\text { Blood saving } \\
\text { bundle vs. } \\
\text { control }\end{array}$ & $\begin{array}{c}15.0 \\
(14.3-15.7) \\
\text { vs. } 43.3 \\
(95 \% \text { CI } \\
41.2-45.3)\end{array}$ & $>72 \mathrm{~h}$ & $\begin{array}{l}8.0 \% \text { vs. } 31.7 \% \text {, } \\
\text { n.s }\end{array}$ & $\begin{array}{c}9.8(8.6 \text { to } \\
11.3) \text { vs. } \\
13.2(10.9 \\
\text { to } 15.4)\end{array}$ \\
\hline $\begin{array}{l}\text { Henry et al. } \\
{[45]}\end{array}$ & 1986 & USA & / & 20 & $\begin{array}{c}\text { General } \\
\text { with car- } \\
\text { diosurgery }\end{array}$ & $\begin{array}{c}\text { Pediatric } \\
\text { tubes vs. } \\
\text { control tubes }\end{array}$ & $\begin{array}{l}\text { Cardiology: } \\
196 \text { vs. } 377 \\
(234-478)^{3} \\
\text { Surgical: } \\
150 \text { vs. } 240 \\
(147-312)^{3}\end{array}$ & / & / & / \\
\hline
\end{tabular}

Median () with interquartile range. Mean \pm with standard deviation. $C=$ controlled. Re $=$ Retrospective $\mathrm{Ra}=$ Randomized. Pro $=$ Prospective . Country codes according to ISO3166. ${ }^{1}$ Short admission. ${ }^{2}$ Long admission ${ }^{3}$ Mean with min and max values. ${ }^{4}$ Median with min and max values. ${ }^{5}$ Value not provided in publication (total laboratory blood volume in both groups of $257.4 \mathrm{~mL} / 7$ days).

A total of 29 observational studies and 9 interventional studies were included. Overall 14 studies were published in the USA, 5 studies in Canada, 4 studies in the United Kingdom, 3 studies in Australia, and 2 studies in Germany. The age of the patients ranged from 46 to 72 years. Only three studies were randomized. In total, 18 studies had a prospective design, 15 studies a retrospective design, and 5 studies had no descriptions about study design. 
Table 3. Observational studies.

\begin{tabular}{|c|c|c|c|c|c|c|c|c|}
\hline Author & Year & $\begin{array}{l}\text { Country/ } \\
\text { Region }\end{array}$ & Study Design & $\begin{array}{c}\text { Number } \\
\text { Population }(n)\end{array}$ & Cohort & $\begin{array}{c}\text { Mean Phlebotomy } \\
\text { Volume/Cumulative } \\
(\mathrm{mL})\end{array}$ & $\begin{array}{c}\text { Mean } \\
\text { Phlebotomy } \\
\text { Volume/d } \\
(\mathrm{mL})\end{array}$ & $\begin{array}{l}\text { Days on ICU } \\
\text { (d) }\end{array}$ \\
\hline Bedayse [46] & 2010 & TTO & Pro & 134 & General ICU & I & $13.5 \pm 4.3$ & I \\
\hline Cioc et al. [9] & 2015 & ROU & Pro & 35 & General ICU & 1 & $18.1 \pm 14.4$ & $9.7 \pm 6.1$ \\
\hline Foulke et al. [47] & 1989 & USA & Pro & 151 & Medical ICU & $168 \pm 18$ & $43.6 \pm 3$ & $4.6 \pm 5$ \\
\hline $\begin{array}{c}\text { Hashimot et al. } \\
{[48]}\end{array}$ & 1982 & USA & Pro & / & Medical ICU & / & $25.8 \pm 15.8$ & / \\
\hline $\begin{array}{l}\text { Holland et al. } \\
{[49]}\end{array}$ & 2020 & UK & Pro & 40 & $\begin{array}{l}\text { General with } \\
\text { cardiac ICU }\end{array}$ & / & $86.3 \pm 19.6$ & / \\
\hline Low et al. [50] & 1995 & USA & Pro & $25^{1}$ & General ICU & I & $70.9 \pm 37.2^{2}$ & I \\
\hline Pabla et al. [32] & 2009 & UK & Pro & 70 & $\begin{array}{c}\text { Acute renal } \\
\text { medicine ward }\end{array}$ & $215.8 \pm 166$ & $\begin{array}{c}55.7 \pm \\
11.23 / \text { week }\end{array}$ & $23.1 \pm 19.8$ \\
\hline Thomas et al. [1] & 2010 & CAN & Pro & 100 & General ICU & I & $24.7 \pm 10.3$ & $7.7 \pm 6.6$ \\
\hline Tosiri et al. [51] & 2010 & THA & Pro & 44 & Medical ICU & $77.8 \pm 59.2$ & $9.8 \pm 5.5$ & 10.89 \\
\hline Vincent et al. [52] & 2002 & $\mathrm{EU}$ & Pro & 1136 & All ICU & I & $41.1 \pm 39.7$ & $4.5 \pm 6.7$ \\
\hline $\begin{array}{l}\text { Vinh Nguyen } \\
\text { et al. [11] }\end{array}$ & 2003 & BEL & Pro & 91 & Medicosurgical & / & $40.3 \pm 15.4$ & $7.7 \pm 9.7$ \\
\hline Witosz et al. [53] & 2021 & POL & Pro & 36 & $\begin{array}{l}\text { Anesthesiology } \\
\text { ICU }\end{array}$ & / & $\begin{array}{l}143.15(121.4- \\
161.65) / \text { week }\end{array}$ & $>7$ day \\
\hline $\begin{array}{c}\text { Andrews et al. } \\
{[54]}\end{array}$ & 1999 & UK & $\operatorname{Re}$ & 65 & Medical ICU & / & $45.74 \pm 16.61$ & $8.5 \pm 8.8$ \\
\hline $\begin{array}{c}\text { Beverina et al. } \\
{[55]}\end{array}$ & 2021 & ITA & $\operatorname{Re}$ & 24 & COVID-ICU & $719(424-1342)^{3}$ & $21.7 \underset{3}{(18.7-26.7)}$ & $29(20-43)^{4}$ \\
\hline Bodley et al. [56] & 2021 & CAN & $\operatorname{Re}$ & $428^{5}$ & $\begin{array}{l}\text { Medical/surgical } \\
\text { ICU }\end{array}$ & / & $48.1 \pm 22.2$ & $12.2 \pm 15.9$ \\
\hline $\begin{array}{l}\text { Chornenki et al. } \\
\text { [57] }\end{array}$ & 2020 & CAN & $\operatorname{Re}$ & 7273 & $\begin{array}{c}\text { Multicenter } \\
\text { medical + } \\
\text { surgical ICU }\end{array}$ & $337 \pm 411$ & $32.3 \pm 27.0$ & $9.3 \pm 13.4$ \\
\hline Corwin et al. [10] & 1995 & LBN/USA & $\operatorname{Re}$ & I & General ICU & $2156 \pm 208^{1}$ & $70 \pm 6^{1}$ & $25 \pm 3^{1}$ \\
\hline Dale et al. [58] & 1993 & 1 & $\operatorname{Re}$ & 14 & Medical ICU & $550(50-2500)^{4,6}$ & 1 & 1 \\
\hline Koch et al. [28] & 2015 & USA & $\operatorname{Re}$ & 1921 & $\begin{array}{c}\text { Cardiac } \\
\text { surgery ICU }\end{array}$ & $332(197,619)^{7}$ & / & $44(24,77)^{7} \mathrm{~h}$ \\
\hline Quinn et al. [33] & 2019 & CAN & $\operatorname{Re}$ & 2052 & Surgical ICU & $145.2 \pm 182.5^{8}$ & $27.2 \pm 20.0^{8}$ & $5.5 \pm 6.1^{8}$ \\
\hline $\begin{array}{l}\text { Salisbury et al. } \\
\text { [29] }\end{array}$ & 2011 & USA & $\begin{array}{c}\mathrm{Re}, \\
\text { multicenter }\end{array}$ & 3551 & Medical ICU & $173.8 \pm 139.3^{9}$ & $24.4 \pm 34.1^{9}$ & / \\
\hline Shaffer et al. [59] & 2007 & NA & $\operatorname{Re}$ & 43 & $\begin{array}{l}\text { Mechanical } \\
\text { ventilated }\end{array}$ & $245 \pm 213^{10}$ & $16 \pm 7$ & / \\
\hline $\begin{array}{c}\text { Smoller et al. } \\
\text { [60] }\end{array}$ & 1986 & USA & $\operatorname{Re}$ & $31^{11}$ & General ICU & $798.1^{11}$ & $73.9^{11}$ & $10.8^{11}$ \\
\hline Tarpey et al. [61] & 1990 & USA & $\operatorname{Re}$ & 26 & ICU & 336 & 66.1 & 5.5 \\
\hline Wisser et al. [62] & 2003 & DEU & $\operatorname{Re}$ & $170^{12}$ & $\begin{array}{c}\text { Medical + } \\
\text { surgical ICU }\end{array}$ & $144^{12}$ & $40^{12}$ & $4^{12}$ \\
\hline Astles et al. [63] & 2009 & UK & / & $151^{13}$ & $\begin{array}{c}\text { Teaching } \\
\text { hospital ICU }\end{array}$ & / & $52.4(0-128.7)^{4}$ & / \\
\hline Eyster et al. [27] & 1973 & USA & I & 93 & Medical ICU & I & $54 \pm 17$ & $20.9 \pm 7.8^{6}$ \\
\hline Smoller [64] & 1989 & USA & I & 41 & Surgical ICU & 120.2 & 32.2 & 1 \\
\hline Ullman et al. [65] & 2016 & AUS & $\begin{array}{l}\text { Cross- } \\
\text { sectional } \\
\text { descriptive } \\
\text { study }\end{array}$ & 50 & Multiple ICUs & / & $37.7(23.1)$ & $64.1 \pm 60.9 \mathrm{~h}$ \\
\hline \multicolumn{9}{|c|}{$\begin{array}{l}\text { Median () with interquartile range. Mean } \pm \text { with standard deviation. Re }=\text { Retrospective. Pro }=\text { Prospective } \\
\text { Country codes according to ISO3166. }{ }^{1} \text { Data for subgroup patients receiving }>10 \text { RBC units. }{ }^{2} \text { Subgroup data: ICL } \\
\text { patients with arterial line during the first } 24 \mathrm{~h} \text { after admission. }{ }^{3} \text { Mean with min and max. }{ }^{4} \text { Median with min and } \\
\text { Max. }{ }^{5} \text { Admission days. }{ }^{6} \text { Entire hospital stay. }{ }^{7} \text { Median }\left[25 \text { th, } 75 \text { th percentiles]. }{ }^{8} \text { Only surgical ICU patients ar }\right. \\
\text { presented. }{ }^{9} \text { Data only for subgroup with moderate to severe hospital acquired anemia. }{ }^{10} \text { For entire hospital sta) } \\
{ }_{11}^{11} \text { Subgroup data presented: ICU patients with arterial line. }{ }^{12} \text { Subgroup data presented: cardiovascular surger } \\
\text { ICU. }{ }^{13} \text { Patient days. }\end{array}$} \\
\hline
\end{tabular}




\subsection{Interventional Trials}

Overall, we found five interventional trials studying the effects of pediatric size blood collection tubes, three intervention trials comparing different blood conservation devices, and one study investigating a comprehensive blood saving bundle (Figure 2). All interventional trials showed that the use of pediatric sized blood collections tubes can significantly reduce the daily amount of blood drawn, for example in a surgical ICU from $240 \mathrm{~mL} / \mathrm{d}$ to $150 \mathrm{~mL} / \mathrm{d}$ [45]. In addition, one trial showed a significant effect of using pediatric tubes vs. adult sized tubes on mortality (5.5\% vs. $1.5 \%$ ) [42].

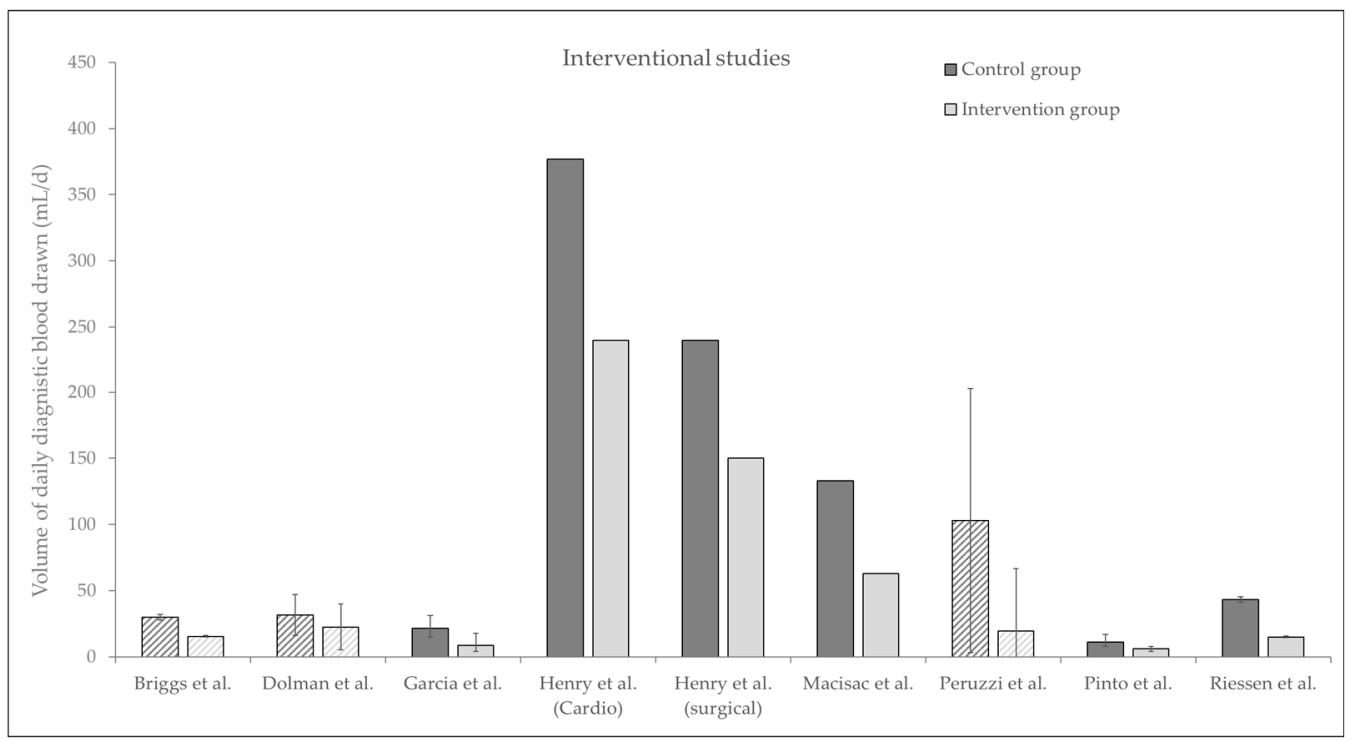

Figure 2. Interventional studies. Daily diagnostic blood drawn in $\mathrm{mL} / \mathrm{d}$, before and after intervention. Plain bars show median with interquartile range, and crosshatched bars show mean values with standard deviation.

\subsection{Observational Trials}

The amount of daily mean diagnostic blood drawn varies between $9.8 \pm 5.5 \mathrm{~mL} / \mathrm{d}$ [51] and $377 \mathrm{~mL} / \mathrm{d}$ [45]. Figure 3 presents the volume of daily diagnostic blood drawn depending on different types of ICUs. Koch et al. showed that patients on cardiothoracic ICUs lose a median of $332 \mathrm{~mL}$ during their stay [28]. Furthermore, Holland et al. showed high volumes of daily blood loss of $62 \mathrm{~mL}$ compared to non-cardiac surgery cohorts [49], suggesting that these cardiac patients are particularly at risk for the development of iatrogenic anemia. Vincent et al. found in $>1000$ patients in Western European ICUs an average blood loss for diagnostics of up to $41.1 \mathrm{~mL} / \mathrm{d}$ [52]. Quinn et al. and Chornenki et al. revealed comparable amounts of blood loss in North American ICU patients and in Canada [33,57]. Most of the studies included data from either surgical or general ICUs. Data from one trial focusing on patients with acute myocardial infarction showed cumulative blood loss of up to $246 \mathrm{~mL}$ due to phlebotomy. The authors also revealed an independent correlation between the increased use of phlebotomy and the risk to develop hospital acquired anemia [29]. 


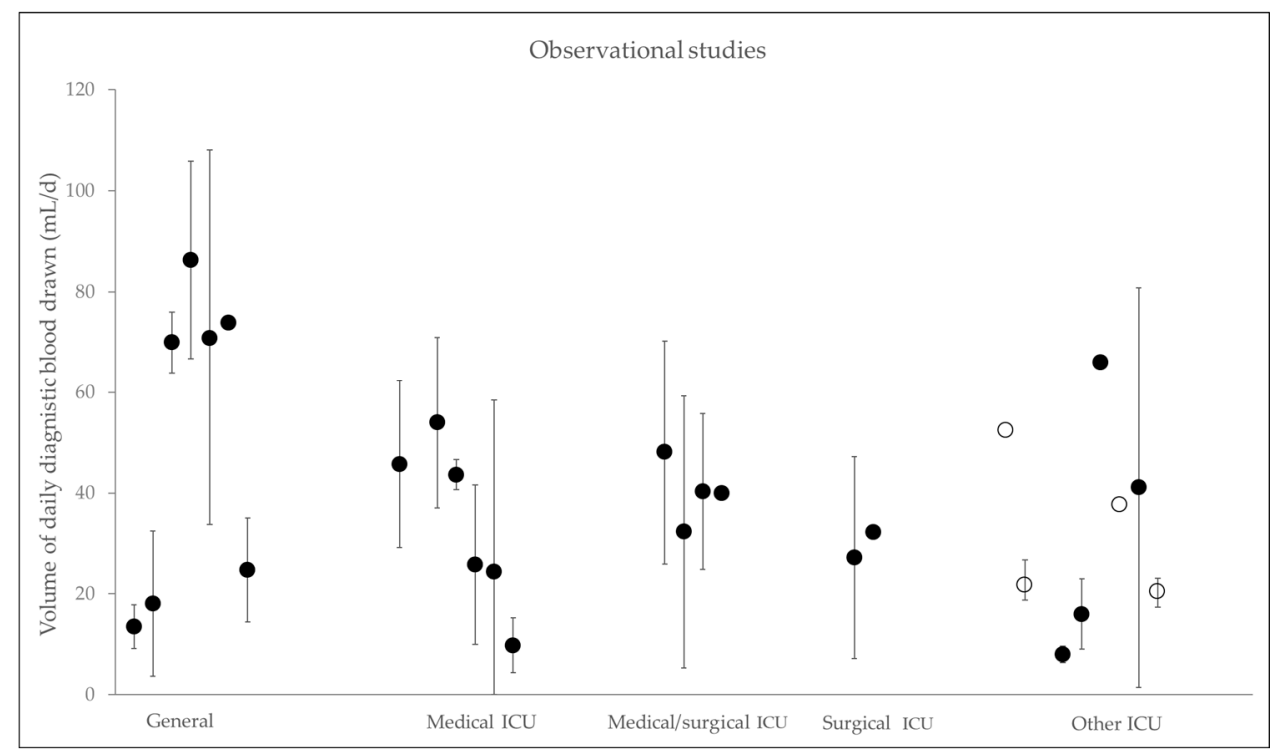

Figure 3. Observational studies. Daily diagnostic blood drawn in $\mathrm{mL} / \mathrm{d}$, clustered into types of ICU. Black dots show mean with standard deviation and white spots show median with interquartile range. References corresponding to Table 3: General ICU [1,9,10,46,49,50,60]; Medical ICU [27,29,47,48,51,54]; Medical/surgical ICU [11,56,57,62]; Surgical ICU [33,64]; other ICU [32,52,53,55,59,61,63,65].

\section{Discussion}

Intensive care patients show a high prevalence of anemia associated with an increased demand for RBC transfusions. Therefore, the question arises as to what extent this problem can be addressed. Previous studies showed high variance in the amount of blood loss during the hospital stay. This scoping review confirmed these findings as blood loss due to diagnostic sampling ranged between $10 \mathrm{~mL}$ and $377 \mathrm{~mL}$ per day in ICU. In patients receiving intensive care for more than 7 days, hemoglobin decreased by $-0.6 \pm 0.6 \mathrm{~g} / \mathrm{dL}$ during the first three days [11]. The median $\mathrm{Hb}$ decreased by about $-10.2 \pm 15 \%$ during the first week on ICU [33].

The most common performed laboratory tests are blood gas analysis (BGA) $(40 \%)$, followed by a coagulation test $(18 \%)$ and complete blood count (14\%) [28]. Serum chemistries are associated with the highest amount of blood drawn per day [29]. The volume of blood typically needed for BGA is approximately $2 \mathrm{~mL}$, for serum chemistries it is $7.5 \mathrm{~mL}$, for citrate tubes it is $4.3 \mathrm{~mL}$, for EDTA it is $2.7 \mathrm{~mL}$, and it is up to $6 \times 10-20 \mathrm{~mL}$ for blood cultures. A systematic review by Siegal et al. pointed out that only $10 \%$ of collected blood is used for laboratory tests, while the remaining blood drawn is discarded [66]. However, the authors encountered a problem in the quality of evidence of studies about blood loss for diagnostics and included only eight studies in their analysis, while $>3000$ studies were screened. Reasons for this are due to different methodologies of the studies, as no recognized standards for the design of comparable studies have been established yet. To a lesser extent, blood volumes are measured in the context of prospective studies, but most authors estimated or calculated their data. In retrospective trials, neither all blood samples nor discarded volumes were recorded. It should also be noted that, depending on the normal distribution, either only the median or only the mean value was given, and these values cannot be fully compared. Furthermore, there are also significant differences between different hospitals in terms of the definition of an ICU, medical care, and geographical location. Interestingly, teaching hospitals show more blood drawn compared to non-teaching hospitals [59]. Most studies do not distinguish between an ICU and the intermediate care unit, or there are no defined specifications about the severity of illness of the patients studied. In order to provide valid conclusions in the future and to be able to determine risk groups precisely, a standardized methodology of trials, including separate quantification of discarded volume and volume used for diagnostics, would be desirable. Furthermore, it 
would be beneficial to specify the hospital and ICU, as well as the patient cohort and to what extent PBM bundles have already been established. Patient characteristics should also be provided, including age, gender, and severity of illness using established scores (e.g., SOFA, APACHE II).

This scoping review shows that diagnostic blood collections can reach high volumes and is a major factor for iatrogenic induced anemia in ICU patients. Anemia is not limited to the immediate hospital stay. Even more than 6 months after discharge from an ICU, anemia is persistent in $53 \%$ of patients [67]. The consequences of anemia in this patient population are severe compared to non-intensive care patients [68]. In a retrospective study from Van der Laan et al., the presence of anemia at ICU discharge was an independent risk factor for a worse outcome [69]. Additionally, an observational study by Smilowitz et al., including $>3000$ patients, identified anemia as a predictor of reduced long-term survival [70]. Transfusion of RBC units is the mainstay to treat anemia [6]. However, on the one hand, patients with RBC transfusion requirements must be monitored more closely with regard to hemoglobin levels, leading to increased iatrogenic blood loss, while on the other hand, transfusion-dependent patients are usually sicker with impaired erythropoiesis compared to non-transfusion-dependent patients [28]. Therefore, some patients have an increased risk for iatrogenic anemia. Single multicenter studies identified the following risk groups suffering from anemia caused by blood loss: septic patients, patients with organ dysfunctions, transplanted patients, patients with renal failure (specifically renal replacement therapy), ventilated patients, patients receiving RBC transfusions, elderly persons, Jehovah's Witnesses, and neonates $[2,11,49,56,71,72]$. Especially in septic patients, a hemoglobin decrease of $-0.82 \pm 0.81 \mathrm{~g} / \mathrm{dL}$ per day within the first 3 days and a decrease of $-0.3 \mathrm{~g} / \mathrm{dL}$ per day for every further day was observed [11]. Long ICU treatment periods also result in higher volumes of diagnostic blood draws. Vincent et al. revealed a positive correlation between the severity of organ dysfunction defined as the SOFA-score and the frequency of blood sampling, resulting in increased iatrogenic blood loss in patients with worse medical conditions [52].

This leads to the question, which improvements can be implemented for blood-sparing techniques in intensive care? In mechanically ventilated patients, for example, blood-saving bundles could reduce diagnostic blood loss by 62\% [44]. Considering that bedside waste per blood draw is $3.9 \mathrm{~mL}$ for arterial lines, $5.5 \mathrm{~mL}$ for central venous catheters, and $6.3 \mathrm{~mL}$ for peripheral venous catheters [56], the use of blood conservation devices is indicated. Siegal et al. showed that blood sampling conservation devices or a venous arterial blood management protection device (VAMP) can significantly reduce diagnostic blood loss by up to $80 \%$ [66]. The establishment of push-pull protocols is effective to significantly reduce the amount of discarded volume [73]. Dale et al. showed, almost 30 years ago, that the amount of blood for L-Thyroxin measurements in laboratory testing is about $0.06 \mathrm{~mL}$ but $5.9 \mathrm{~mL}$ was phlebotomized [58]. In addition to the discarded volume, the use of pediatric-size tubes can also reduce the amount of phlebotomized volume by up to $50 \%$ and provide reliable analytics [22,38,74,75]. In Figure 4, examples of standard size tubes and reduced sized tubes are displayed. As part of the reduction in tube filling volume, a total of approximately $40 \mathrm{~L}$ of patient blood could be saved per year (about 3700 treatment days) in a general surgical ICU with 12 beds at University Hospital Würzburg (Table 4). Calculated to the entire University Hospital Würzburg, a complete reduction in the filling volume of all blood tubes used would result in a saving of over $1600 \mathrm{~L}$ of patient blood per year. 


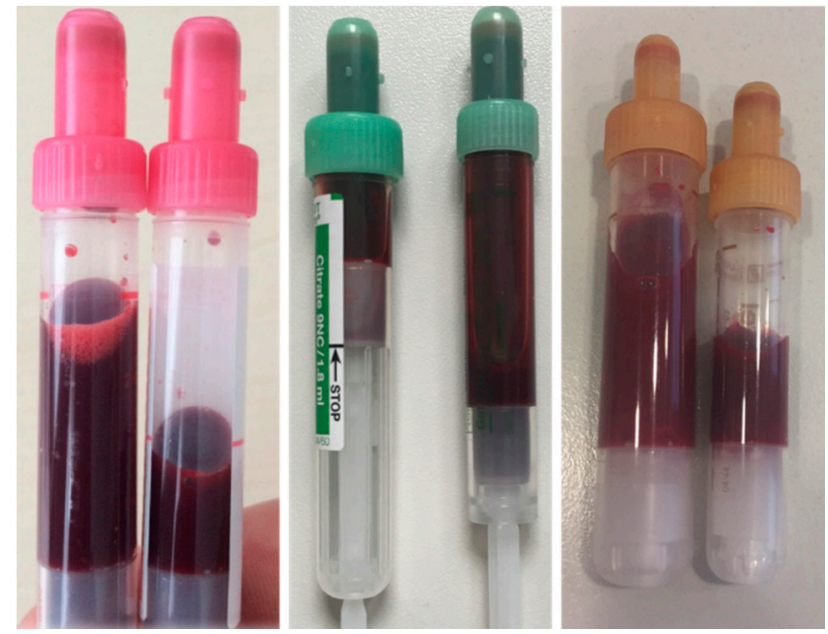

Figure 4. EDTA, citrate tubes, and serum chemistry with standard volume and reduced blood volume.

Table 4. Effect of pediatric sized tubes in a 12-bed surgical ICU.

\begin{tabular}{cccc}
\hline & Normal Sized $(\mathbf{m L})$ & Reduced Size $(\mathbf{m L})$ & $\Delta(\mathbf{m L})$ \\
\hline EDTA & 13,317 & 7891 & 5425 \\
\hline Citrate tubes & 24,871 & 10,411 & 14,460 \\
\hline Serum chemistry & 39,390 & 24,684 & 14,706 \\
\hline
\end{tabular}

Results of a laboratory-chemical extrapolation of the savings achieved by reducing the filling volume of blood tubes per year with about 3700 treatment days on a 12-bed surgical ICU at University Hospital Würzburg. The filling volumes are assumed for EDTA $(2.7 \mathrm{~mL}$ vs. $1.6 \mathrm{~mL})$, citrate tubes $(4.3 \mathrm{~mL}$ vs. $1.8 \mathrm{~mL})$, and serum chemistry $(7.5 \mathrm{~mL}$ vs. $4.7 \mathrm{~mL})$. The last column shows the respective calculated amount of blood saved per year. $\Delta=$ delta (normal sized - reduced size).

In addition to the phlebotomized volume, an effort should also be made to decrease the frequency of blood sampling. Educational initiatives for reducing iatrogenic anemia should be considered, including all health care professionals and a feedback system to the ordering clinicians [76]. In addition, all laboratory values obtained should be shared with all medical disciplines to avoid redundant laboratory analyses. Furthermore, blood samples should be shared between the laboratories to reduce blood drawn. The indication for the determination of laboratory values should not be made according to strict standards but should be individually adapted to the respective patient [1]. This restricted indication should also apply to the placement of arterial line catheters. Low et al. has shown that patients with a comparable APACHE II score had $44 \%$ more phlebotomized blood volume/d if an arterial line was implemented [50]. Non-invasive measurement of glucose and hemoglobin levels by point-of-care diagnostics or continuous intravascular monitoring sensors should be considered to reduce the frequency of blood sampling $[77,78]$.

\section{Conclusions}

Anemia may worsen the outcome of patients receiving intensive care. One of the most important iatrogenic factors aggravating anemia is blood sampling for diagnostic purposes. Vulnerable patients with acute myocardial infarction or pre-existing diseases, such as COPD, congestive heart failure, and chronic kidney disease, could benefit from patient centered PBM with reduced iatrogenic blood loss. Patient groups at risk for frequent blood sampling include patients with sepsis, organ transplants, elderly patients, patients with multiple organ failure, prolonged ICU stay, and pediatric patients. Blood sparing devices and small-volume blood collection tubes, frequent training on PBM bundles, individual settings for target hemoglobin levels, and frequency of blood sampling, as well as systematic documentation, are concepts shown to be effective, improving outcome and 
reducing the need for $\mathrm{RBC}$ transfusion. In conclusion, iatrogenic blood loss has been a well-known problem for many years. Yet not much has changed to tackle this issue. There is an urgent need to increase awareness of blood loss due to diagnostic blood sampling, and solutions such as closed-loop systems, reduction of blood sample volume, and frequency of laboratory tests should be implemented.

Author Contributions: The development of the search term was realized by P.H., S.C. and P.M. The systematic search was carried out by P.H. and S.H. Identified articles were accurate analyzed by P.H., S.H., S.C. and P.M. The manuscript was drafted by P.H. and critically reviewed by S.H., A.S., D.R., J.S., U.S., S.C. and P.M. The design of the graphics was realized by A.S. J.S. and U.S. performed the extrapolation for the amount of blood saved due to reduced blood collection tubes. All authors gave substantial contributions to the conception of the work and interpretation of data. All authors have read and agreed to the published version of the manuscript.

Funding: This paper was not financially supported by third parties.

Institutional Review Board Statement: Not applicable.

Informed Consent Statement: Not applicable.

Data Availability Statement: Not applicable.

Acknowledgments: We would like to thank Stephanie Weibel for her support.

Conflicts of Interest: P.M. received honoraria for scientific lectures from Belgium Red Cross, Biotest, CSL Behring GmbH, Bundesamt für Bevoelkerungsschutz und Katastrophenhilfe (BKK), Fresenius, Haemonetics, Landesärztekammer Sachsen, Landesärztekammer Hessen, Masimo, Radiometer, Schöechl medical Education, Thieme-Verlag, Trillium Diagnostik, Werfen GmbH, and ViforPharma GmbH. D.R. received honoraria from CSL Behring GmbH. P.H., SH., A.S., J.S. and S.C. do not declare any conflict of interest.

\author{
Abbreviations \\ ARDS Acute respiratory distress syndrome \\ BGA Blood gas analysis \\ COPD chronic obstructive pulmonary disease \\ CRRT continuous renal replacement therapy \\ ECMO extra corporal membrane oxygenation \\ EPO Erythropoietin \\ ESA Erythropoiesis-stimulating agents \\ $\mathrm{Hb} \quad$ Hemoglobin \\ ICU Intensive care unit \\ PBM Patient Blood Management \\ RCT Randomized controlled trial \\ RBC Red blood cell \\ TNF Tumor necrosis factor \\ VAMP venous arterial blood management protection device \\ WHA World Health Assembly
}

\title{
Appendix A
}

Search term: ((Blood draw*[TIAB]) OR (Blood conservation[TIAB]) OR (Blood conserving[TIAB]) OR (Phlebotomy[TIAB]) OR (Phlebotomi*[TIAB]) OR (Diagnostic blood loss[TIAB]) OR (Iatrogenic anemia[TIAB]) OR (Iatrogenic anemia[TIAB]) OR (Iatrogen anemia[TIAB]) OR (Iatrogen anemia[TIAB]) OR (Iatrogenic blood loss[TIAB]) OR (Blood sampling[TIAB]) OR (bloodletting[TIAB]) OR (blood taken[TIAB]) OR (blood test*[TIAB]) OR (laboratory test ${ }^{*}[$ TIAB]) OR (nosocomial anemia[TIAB]) OR (nosocomial anemia[TIAB]) OR (small volume tubes[TIAB])) AND ((Critically ill[TIAB]) OR (Intensive care[TIAB]) OR (Mechanically ventilated[TIAB]) OR (ICU[TIAB]) OR (Critical care[TIAB]) OR (Intensive therapy[TIAB])). 


\section{References}

1. Thomas, J.; Jensen, L.; Nahirniak, S.; Gibney, R.T. Anemia and blood transfusion practices in the critically ill: A prospective cohort review. Heart Lung 2010, 39, 217-225. [CrossRef] [PubMed]

2. Walsh, T.S.; Saleh, E.E. Anaemia during critical illness. Br. J. Anaesth. 2006, 97, 278-291. [CrossRef] [PubMed]

3. Baron, D.M.; Hochrieser, H.; Posch, M.; Metnitz, B.; Rhodes, A.; Moreno, R.P.; Pearse, R.M.; Metnitz, P.; European Surgical Outcomes Study group for Trials Groups of European Society of Intensive Care Medicine and the European Society of Anaesthesiology. Preoperative anaemia is associated with poor clinical outcome in non-cardiac surgery patients. Br. J. Anaesth. 2014, 113, 416-423. [CrossRef]

4. Musallam, K.M.; Tamim, H.M.; Richards, T.; Spahn, D.R.; Rosendaal, F.R.; Habbal, A.; Khreiss, M.; Dahdaleh, F.S.; Khavandi, K.; Sfeir, P.M.; et al. Preoperative anaemia and postoperative outcomes in non-cardiac surgery: A retrospective cohort study. Lancet 2011, 378, 1396-1407. [CrossRef]

5. $\quad$ Bellmann-Weiler, R.; Lanser, L.; Barket, R.; Rangger, L.; Schapfl, A.; Schaber, M.; Fritsche, G.; Woll, E.; Weiss, G. Prevalence and Predictive Value of Anemia and Dysregulated Iron Homeostasis in Patients with COVID-19 Infection. J. Clin. Med. 2020, 9, 2429. [CrossRef] [PubMed]

6. McEvoy, M.T.; Shander, A. Anemia, bleeding, and blood transfusion in the intensive care unit: Causes, risks, costs, and new strategies. Am. J. Crit. Care 2013, 22, eS1-eS13.quiz eS14. [CrossRef]

7. Rasmussen, L.; Christensen, S.; Lenler-Petersen, P.; Johnsen, S.P. Anemia and 90-day mortality in COPD patients requiring invasive mechanical ventilation. Clin. Epidemiol. 2010, 3, 1-5. [CrossRef]

8. Shah, A.; Stanworth, S.J.; Lee, A.; Johnston, L.; Docherty, A.B. Prevalence, management and outcomes associated with anaemia in ICU survivors: A retrospective study. Anaesthesia 2021, 76, 1421-1423. [CrossRef] [PubMed]

9. Cioc, A.; Fodor, R.; Benedek, O.; Moldovan, A.; Copotoiu, S.-M. Blood sampling as a cause of anemia in a general ICU_a pilot study. Rom. J. Anaesth. Intensive Care 2015, 22, 13-16.

10. Corwin, H.L.; Parsonnet, K.C.; Gettinger, A. RBC transfusion in the ICU. Is there a reason? Chest 1995, 108, 767-771. [CrossRef]

11. Nguyen, B.V.; Bota, D.P.; Melot, C.; Vincent, J.L. Time course of hemoglobin concentrations in nonbleeding intensive care unit patients. Crit. Care Med. 2003, 31, 406-410. [CrossRef] [PubMed]

12. Schobersberger, W.; Hobisch-Hagen, P.; Fuchs, D.; Hoffmann, G.; Jelkmann, W. Pathogenesis of anaemia in the critically ill patient. Clin. Intensive Care 1998, 9, 111-117. [CrossRef]

13. Corwin, H.; Gettinger, A.; Pearl, R.; Fhnk, M.; Levy, M.; Shapiro, M.; Corwin, M.; Colton, T.; Group, E.C.c.t. Efficacy of recombinant human erythropoietin in critically ill patients. JAMA 2002, 288, 2827-2835. [CrossRef]

14. Weiss, G.; Ganz, T.; Goodnough, L.T. Anemia of inflammation. Blood 2019, 133, 40-50. [CrossRef]

15. Nicolas, v.A.; Christian, M.; Stefan, S.; Ulrich, F.; Kai-Uwe, E. Important role of nondiagnostic blood loss and blunted erythropoietic response in the anemia of medical intensive care patients. Crit. Care Med. 1999, 27, 2630-2639.

16. Scharte, M.; Fink, M.P. Red blood cell physiology in critical illness. Crit. Care Med. 2003, 31, S651-S657. [CrossRef] [PubMed]

17. Jelkmann, I.; Jelkmann, W. Impact of erythropoietin on intensive care unit patients. Transfus. Med. Hemother. 2013, 40, 310-318. [CrossRef] [PubMed]

18. Jurado Rafael, L. Iron, Infections, and Anemia of Inflammation. Clin. Infect. Dis. 1997, 25, 888-895. [CrossRef] [PubMed]

19. Rodriguez, R.M.; Corwin, H.L.; Gettinger, A.; Corwin, M.J.; Gubler, D.; Pearl, R.G. Nutritional deficiencies and blunted erythropoietin response as causes of the Amemia of critical illness. J. Crit. Care 2001, 16, 36-41. [CrossRef]

20. Rawal, G.; Kumar, R.; Yadav, S.; Singh, A. Anemia in Intensive Care: A Review of Current Concepts. J. Crit. Care Med. 2016, 2, 109-114. [CrossRef] [PubMed]

21. Graw, J.A.; Baron, D.M.; Francis, R.C. Die Bedeutung der Hämolyse in Anästhesie und Intensivmedizin. Anästhesiol. Intensivmed. Notf. Schmerzther. 2018, 53, 296-305. [CrossRef]

22. Dolman, H.S.; Evans, K.; Zimmerman, L.H.; Lavery, T.; Baylor, A.E.; Wilson, R.F.; Tyburski, J.G. Impact of minimizing diagnostic blood loss in the critically ill. Surgery 2015, 158, 1083-1087. [CrossRef]

23. Cook, D.; Fuller, H.; Guyatt, G.H.; Marshall, J.C.; Leasa, D.; Hall, R.; Winton, T.L.; Rutledge, F.; Todd, T.J.; Roy, P.; et al. Risk factors for GI bleeding in Critcally ill patients. N. Engl. J. Med. 1994, 330, 377-381. [CrossRef]

24. Arnold, D.M.; Donahoe, L.; Clarke, F.J.; Tkacyzk, A.J.; Heels-Ansdell, D.; Zytaruk, N.; Cook, R.; Webert, K.; McDonald, E.; Cook D.J. Bleeding during critical illness: A prospective cohort study using a new measurment tool. Clin. Invest. Med. 2007, 30, E93-E102. [CrossRef] [PubMed]

25. Granholm, A.; Zeng, L.; Dionne, J.C.; Perner, A.; Marker, S.; Krag, M.; MacLaren, R.; Ye, Z.; Moller, M.H.; Alhazzani, W.; et al. Predictors of gastrointestinal bleeding in adult ICU patients: A systematic review and meta-analysis. Intensive Care Med. 2019, 45, 1347-1359. [CrossRef]

26. Marks, P.W. Coagulation disorders in the ICU. Clin. Chest Med. 2009, 30, 123-129. [CrossRef] [PubMed]

27. Eyster, E.; Bernene, J. Nosocomial Anemia. JAMA 1973, 223, 73-74. [CrossRef]

28. Koch, C.G.; Reineks, E.Z.; Tang, A.S.; Hixson, E.D.; Phillips, S.; Sabik, J.F., 3rd; Henderson, J.M.; Blackstone, E.H. Contemporary bloodletting in cardiac surgical care. Ann. Thorac. Surg. 2015, 99, 779-784. [CrossRef]

29. Salisbury, A.C. Diagnostic Blood Loss From Phlebotomy and Hospital-Acquired Anemia During Acute Myocardial Infarction. Arch. Intern. Med. 2011, 171, 1646-1653. [CrossRef] 
30. Chant, C.; Wilson, G.; Friedrich, J.O. Anemia, transfusion, and phlebotomy practices in critically ill patients with prolonged ICU length of stay: A cohort study. Crit. Care 2006, 10, R140. [CrossRef] [PubMed]

31. Baron, R.M.; Christman, J.W.; Liu, K.D.; Matthay, M.A.; Self, W.H.; McVerry, B.J.; Hite, R.D.; Paine, R., 3rd; Wurfel, M.M.; Shapiro, N.I.; et al. Monitoring Research Blood Sampling in Critically Ill Patients: Avoiding Iatrogenic Anemia. Am. J. Respir. Crit. Care Med. 2020, 202, 885-887. [CrossRef] [PubMed]

32. Pabla, L.; Watkins, E.; Doughty, H.A. A study of blood loss from phlebotomy in renal medical inpatients. Transfus. Med. 2009, 19, 309-314. [CrossRef] [PubMed]

33. Quinn, J.G.; Levy, A.R.; Cheng, C.K.; Doucette, S.; Theriault, C.; Doiron, D.; Kiberd, B.A.; Tennankore, K.K. A contemporary description of patients' estimated blood losses from diagnostic phlebotomy in a census of hospital episodes from a Canadian tertiary care center. Transfusion 2019, 59, 2849-2856. [CrossRef] [PubMed]

34. WHA63.12. Availability, Safety and Quality of Blood Products. Available online: https://apps.who.int/iris/handle/10665/3086 (accessed on 5 December 2021).

35. Meybohm, P.; Richards, T.; Isbister, J.; Hofmann, A.; Shander, A.; Goodnough, L.T.; Munoz, M.; Gombotz, H.; Weber, C.F.; Choorapoikayil, S.; et al. Patient Blood Management Bundles to Facilitate Implementation. Transfus. Med. Rev. 2017, 31, 62-71. [CrossRef] [PubMed]

36. Goodnough, L.T.; Shander, A.; Brecher, M.E. Transfusion medicine: Looking to the future. Lancet 2003, 361, 161-169. [CrossRef]

37. Tricco, A.C.; Lillie, E.; Zarin, W.; O’Brien, K.K.; Colquhoun, H.; Levac, D.; Moher, D.; Peters, M.D.J.; Horsley, T.; Weeks, L.; et al. PRISMA Extension for Scoping Reviews (PRISMA-ScR): Checklist and Explanation. Ann. Intern. Med. 2018, 169, 467-473. [CrossRef]

38. Briggs, E.N.; Hawkins, D.J.; Hodges, A.M.; Monk, A.M. Small volume vacuum phlebotomy tubes: A controlled beforeandand-after study of a paitent blood management initiative in an Australian adult intensive care unit. Crit. Care Resusc. 2019, 21, 251-257.

39. Barreda Garcia, J.; Xian, J.Z.; Pedroza, C.; Salahuddin, M.; Mak, G.; Keene, A.; Cherian, S.V.; Young, A.Y.; Vijhani, P.; Doshi, P.B. Pediatric size phlebotomy tubes and transfusions in adult critically ill patients: A pilot randomized controlled trial. Pilot Feasibility Stud. 2020, 6, 112. [CrossRef]

40. Macisaac, C.M.; Presneill, J.J.; Boyce, C.A.; Byron, K.L.; Cade, J.F. The Influence of a Blood Conserving Device on Anaemia in Intensive Care Patients. Anaesth. Intensive Care 2003, 31, 653-657.

41. Peruzzi, W.T.; Parker, M.A.; Lichtenthal, P.R.; Cochran-Zull, C.; Toth, B.; Blake, M. A clinical evaluation of a blood conservation device in medical intensive care unit patients. Crit. Care Med. 1993, 21, 501-506. [CrossRef]

42. Pinto, T.; Belley-Cote, E.; Esmail, A.; Zotova, E.; Meeks, B.; Connolly, S.; Siegal, D.M. Small-Volume Tubes to Reduce Transufusion (STRATUS): A Pilot Study. Blood 2018, 132, 825. [CrossRef]

43. Silver, M.J.; Li, Y.H.; Gragg, L.A.; Jubran, F.; Stoller, J.K. Reduction of blood loss from diagnostic sampling in critically ill patients using a blood-conserving arterial line system. Chest 1993, 104, 1711-1715. [CrossRef]

44. Riessen, R.; Behmenburg, M.; Glumenstock, G.; Guenon, D.; Enkel, S.; Schäfer, R.; Haap, M. A Simple "Blood-Saving Bundle" Reduces Diagnostic Blood Loss and the Transfusion Rate in Mechanically Ventilated Patients. PLoS ONE 2015, 10, e0138879. [CrossRef] [PubMed]

45. Mitchell, H.L.; Warren, G.L.; Peter, F.J. Iatrogenic Anemia. Am. J. Surg. 1986, 151, 362-363.

46. Bedayse, N.; Hariharan, S.; Chen, D. Red Cell Transfusion Practices and the Impact of Phlebotomy in an Adult Intensive care unit in trinidad. West. Indian Med. J. 2010, 59, 67-72.

47. Foulke, G.E.; Harlow, D.J. Effective measures for reducing blood loss from diagnostic laboratory test in intensive care unit patients. Crit. Care Med. 1989, 17, 1143-1145. [CrossRef]

48. Hashimoto, F. Bleeding Less for Diagnostics. JAMA 1982, 248, 171. [CrossRef] [PubMed]

49. Holland, J.; Peralta, R.M.; Moss, R.L.; Feane, K.; Uprichard, J. A single-centre review of iatrogenic anaemia in adult intensive care Transfus. Med. 2020, 30, 196-200. [CrossRef] [PubMed]

50. Low, L.L.; Harrington, G.R.; Stoltzfus, D.P. The effect of arterial lines on blood-drawing practices and costs in intensive care units. Chest 1995, 108, 216-219. [CrossRef]

51. Pitima, T.; Nonglak, K.; Apichart, K. Approximate Iatrogenic Blood Loss in Medical Intensive Care Patients and the Causes of Anemia. J. Med. Assoc. Thai 2010, 93, 271-276.

52. Vincent, J.L.; Baron, J.-F.; Reinhart, K.; Gattinoni, L.; Thijs, L.; Webb, A.; Meier-Hellmann, A.; Nollet, G.; Peres-Bota, D.; Investigators, A. Anemia and Blood Transfusion in Critically ill Patients. JAMA 2002, 288, 1499-1507. [CrossRef] [PubMed]

53. Witosz, K.; Wojnarowicz, O.; Krzych, L.J. Iatrogenic blood loss due to daily laboratory testing and the risk of subsequent anaemia in intensive care unit patients: Case series. Acta Biochim. Pol. 2021, 68, 135-138. [CrossRef] [PubMed]

54. Andrews, T.; Waterman, H.; Hillier, V. Blood gas analysis: A study of blood loss in intensive care. J. Adv. Nurs. 1990, 30, 851-857. [CrossRef] [PubMed]

55. Beverina, I.; Borotto, E.; Novelli, C.; Radrizzani, D.; Brando, B. Iatrogenic anaemia and transfusion thresholds in ICU patients with COVID-19 disease at a tertiary care hospital. Transfus. Apher. Sci. 2021, 60, 103068. [CrossRef]

56. Bodley, T.; Chan, M.; Levi, O.; Clarfield, L.; Yip, D.; Smith, O.; Friedrich, J.O.; Hicks, L.K. Patient harm associated with serial phlebotomy and blood waste in the intensive care unit: A retrospective cohort study. PLoS ONE 2021, 16, e0243782. [CrossRef] [PubMed] 
57. Jackson Chornenki, N.L.; James, T.E.; Barty, R.; Liu, Y.; Rochwerg, B.; Heddle, N.M.; Siegal, D.M. Blood loss from laboratory testing, anemia, and red blood cell transfusion in the intensive care unit: A retrospective study. Transfusion 2020, 60, 256-261. [CrossRef] [PubMed]

58. Dale, J.C.; Pruett, S.K. Phlebotomy-A Minimalist Approach. Mayo Clin. Proc. 1993, 68, 249-255. [CrossRef]

59. Shaffer, C. Diagnostic blood loss in mechanically ventilated patients. Heart Lung 2007, 36, 217-222. [CrossRef] [PubMed]

60. Smoller, B.R.; Kruskall, M.S. Phlebotomy for diagnostic laboratory tests in adults. Pattern of use and effect on transfusion requirements. N. Engl. J. Med. 1986, 314, 1233-12335. [CrossRef]

61. Tarpey, J.; Lawler, P.G. Iatrogenic anaemia: A survey of venesection in patients in the intensive therapy unit. Anaesthesia 1990, 45, 396-398. [CrossRef]

62. Wisser, D.; Ackern, K.v.; Knoll, E.; Wisser, H.; Bertsch, T. Blood Loss from Laboratory Tests. Clin. Chem. 2003, 49, 1654-1655. [CrossRef]

63. Astles, T. Iatrogenic Anaemia in the Critically Ill: A Survey of the Frequency of Blood Testing in a Teaching Hospital Intensive Care Unit. J. Intensive Care Soc. 2009, 10, 279-281. [CrossRef]

64. Smoller, B.R.; Kruskall, M.S.; Horowitz, G.L. Reducing Adult Phlebotomy Blood Loss with the use of pediatric sized blood collection tubes. A.J.C.P. 1989, 91, 701-703. [CrossRef] [PubMed]

65. Ullman, A.J.; Keogh, S.; Coyer, F.; Long, D.A.; New, K.; Rickard, C.M. 'True Blood' The Critical Care Story: An audit of blood sampling practice across three adult, paediatric and neonatal intensive care settings. Aust. Crit. Care 2016, 29, 90-95. [CrossRef] [PubMed]

66. Siegal, D.M.; Manning, N.; Jackson Chornenki, N.L.; Hillis, C.M.; Heddle, N.M. Devices to Reduce the Volume of Blood Taken for Laboratory Testing in ICU Patients: A Systematic Review. J. Intensive Care Med. 2020, 35, 1074-1079. [CrossRef] [PubMed]

67. Bateman, A.P.; McArdle, F.; Walsh, T.S. Time course of anemia during six months follow up following intensive care discharge and factors associated with impaired recovery of erythropoiesis. Crit. Care Med. 2009, 37, 1906-1912. [CrossRef]

68. Warner, M.A.; Hanson, A.C.; Frank, R.D.; Schulte, P.J.; Go, R.S.; Storlie, C.B.; Kor, D.J. Prevalence of and Recovery From Anemia Following Hospitalization for Critical Illness Among Adults. JAMA Netw Open 2020, 3, e2017843. [CrossRef]

69. van der Laan, S.; Billah, T.; Chi, C.; Lai, C.; Litton, E. Anaemia among intensive care unit survivors and association with days alive and at home: An observational study. Anaesthesia 2021, 76, 1352-1357. [CrossRef]

70. Smilowitz, N.R.; Oberweis, B.S.; Nukala, S.; Rosenberg, A.; Zhao, S.; Xu, J.; Stuchin, S.; Iorio, R.; Errico, T.; Radford, M.J.; et al Association between Anemia, Bleeding, and Transfusion with Long-term Mortality Following Noncardiac Surgery. Am. J. Med. 2016, 129, 315-323 e312. [CrossRef]

71. Zelie, D.F.; Nancy, S.L. Nursing Strategies to Minimize Blood Loss Associated With Phlebotomy. AACN Clin. Issues 1996, 7, 277-287.

72. Loftus, T.J.; Brakenridge, S.C.; Murphy, T.W.; Nguyen, L.L.; Moore, F.A.; Efron, P.A.; Mohr, A.M. Anemia and blood transfusion in elderly trauma patients. J. Surg Res. 2018, 229, 288-293. [CrossRef] [PubMed]

73. McBride, C.; Miller-Hoover, S.; Proudfoot, J.A. A Standard Push-Pull Protocol for Waste-Free Sampling in the Pediatric Intensive Care Unit. J. Infus. Nurs. 2018, 41, 189-197. [CrossRef] [PubMed]

74. Wu, Y.; Spaulding, A.C.; Borkar, S.; Shoaei, M.M.; Mendoza, M.; Grant, R.L.; Barber, B.W.; Johns, G.S.; Franco, P.M. Reducing Blood Loss by Changing to Small Volume Tubes for Laboratory Testing. Mayo Clin. Proc. Innov. Qual. Outcomes 2021, 5, 72-83. [CrossRef] [PubMed]

75. Adam, E.H.; Zacharowski, K.; Hintereder, G.; Zierfuss, F.; Raimann, F.; Meybohm, P. Validation of a New Small-Volume Sodium Citrate Collection Tube for Coagulation Testing in Critically Ill Patients with Coagulopathy. Clin. Lab. 2018, 64, 1083-1089. [CrossRef]

76. Eaton, K.P.; Levy, K.; Soong, C.; Pahwa, A.K.; Petrilli, C.; Ziemba, J.B.; Cho, H.J.; Alban, R.; Blanck, J.F.; Parsons, A.S. EvidenceBased Guidelines to Eliminate Repetitive Laboratory Testing. JAMA Intern. Med. 2017, 177, 1833-1839. [CrossRef]

77. Pilackas, K.; El-Oshar, S.; Carter, C. Clinical Reliability of Point-of-Care Glucose Testing in Critically Ill Patients. J. Diabetes Sci. Technol. 2020, 14, 65-69. [CrossRef]

78. Crane, B.C.; Barwell, N.P.; Gopal, P.; Gopichand, M.; Higgs, T.; James, T.D.; Jones, C.M.; Mackenzie, A.; Mulavisala, K.P.; Paterson, W. The Development of a Continuous Intravascular Glucose Monitoring Sensor. J. Diabetes Sci. Technol. 2015, 9, 751-761. [CrossRef] 